Volume 3 Nomor 1, Maret 2021, Halaman $44-52$.

\title{
Pelatihan Cara Cepat Perhitungan Perkalian Menggunakan Metode Garis Untuk Siswa SD Di Desa Sukadana Kecamatan Tukdana
}

\author{
Sudirman ${ }^{1)}$, Siti Soleha ${ }^{2)}$ \\ ${ }^{1,2)}$ Program Studi Pendidikan Matematika Universitas Wiralodra \\ Email: $\underline{\text { sudirman@ unwir.ac.id }}^{1}$, $\underline{\text { sitisoleha063@ gmail.com }}^{2}$
}

\begin{abstract}
Abstrak
Operasi perkalian bilangan bulat sebagai salah satu ilmu dasar dari matematika, dipelajari sejak jenjang Sekolah Dasar. Namun demikian masih banyak siswa yang mengalami kesulitan dalam meyelesaikan operasi perkalian bilangan bulat. Hal ini sangat mungkin terjadi, dikarenakan pembelajaran perkalian bilangan bulat di Sekolah Dasar belum menggunakan metode pembelajaran yang sesuai dengan tahap perkembangan siswa. Sejak SD anak dipaksa untuk berfikir secara abstrak, dalam pembelajaran perkalian cenderung lebih mengedepankan menghafal dari pada pemahaman. Maka dari itu, dalam rangka pengabdian kepada masyarakat kelompok kami mengadakan bimbingan belajar sehingga siswa mendapatkan pembelajaran yang inovatif. Dengan metode garis belajar perkalian bilangan bulat menjadi lebih konkret. Para siswa tidak hanya selalu dihadapkan dengan angka-angka yang abstrak. Akan tetapi angka-angka tersebut dinyatakan dengan ruas garis yang saling berpotongan, dalam menentukan hasil perkalian, siswa tinggal menghitung banyaknya titik potong garis-garis yang dibuatnya. Hasil dari kegiatan tersebut, diperoleh kemajuan dari motivasi siswa-siswi untuk belajar matematika dan memahami operasi perkalian dengan metode yang disampaikan.
\end{abstract}

Kata Kunci: Bimbingan belajar matematika, Perkalian, Metode Garis.

\begin{abstract}
Abtract
The operation of multiplying integers as one of the basic sciences of mathematics, has been studied since Elementary School. However, there are still many students who have difficulty completing the multiplication of integers. This is very likely to happen, because learning the multiplication of integers in elementary schools has not used learning methods that are appropriate to the stages of student development. Since elementary school, children are forced to think abstractly, in learning multiplication tends to prioritize memorization rather than understanding. Therefore, in the context of community service, our group conducts tutoring so that students get innovative learning. With the line method learning the multiplication of integers becomes more concrete. Students are not only always faced with abstract numbers. However, these numbers are expressed as line segments that intersect each other, in determining the product of the multiplication, students just need to calculate the number of intersection points of the lines they make. The results of these activities, obtained progress from the
\end{abstract}


students' motivation to learn mathematics and understand the multiplication operation with the method presented.

Keywords: Math tutoring, Multiplication, Line Method.

DOI: https://doi.org/10.31943/abdi.v3i1.35

\section{A. PENDAHULUAN}

\section{Analisis Situasi}

Matematika merupakan salah satu mata pelajaran yang paling banyak dihindari oleh siswa, hal ini dikarenakan mata pelajaran matematika banyak menggunakan rumus dan sulit dimengerti(Azhari, 2017; Sholihah \& Mahmudi, 2015; Siregar, 2017; Yeni, 2015). Persepsi ini sudah tertanam oleh siswa sejak masih duduk di bangku sekolah dasar. Kondisi seperti ini perlu dibenahi sejak dini agar persepsi tersebut tidak berkelanjutan. Penggunaan metode-metode yang menarik merupakan salah satu cara yang digunakan untuk meningkatkan motivasi dalam belajar(Achadah, 2019; DS, 2016; Sari et al., 2019). Seperti halnya dengan matematika. Penggunaan metode yang dianggap mempemudah siswa dalam melakukan perhitungan dasar akan berdampak positif terhadap minat siswa dalam belajar matematika.

Di Desa Sukadana Kecamatan Tukdana ini masih belum terdapat tempat bimbingan belajar. Siswa-siswi hanya belajar melalui mushola-mushola terdekat yang dianggap bisa membantu persoalan tentang mata pelajaran di sekolah. Tetapi pada kenyataannya, pengurus masjid atau warga yang menjadi tenaga pendidik di mushola tersebut hanya mampu memberikan penjelasan yang bersifat umum sehingga siswa-siswi memiliki minat yang rendah untuk belajar, khususnya pada mata pelajaran matematika. Bimbingan belajar sebagai suatu proses yang tak hanya untuk memperbaiki atau mengarahkan hasil belajar siswa atau dalam hal akademiknya saja, tetapi juga dapat membuat siswa menjadi pribadi yang aktif dalam lingkungan sosial (Supriatna, Yuliawati, dan Firmansyah, 2017).

Bimbingan belajar ditandai dengan diberikannya jam pelajaran khusus yang biasanya dilakukan di luar jam pelajaran sekolah. Bimbingan belajar membahas materi-materi yang rata-rata masih belum dipahami oleh siswa. Bimbingan belajar dilakukan dengan pemilihan metode dan strategi yang tepat dan menarik. Hal ini dilakukan agar semua permasalahan siswa dalam belajar dapat terselesaikan dengan baik sehingga hasil belajar yang dicapai oleh siswa akan maksimal (Sari, 2015).

Dengan kondisi seperti ini, warga desa mengharapkan bantuan tenaga pendidik pada bimbingan belajar yang memiliki kemampuan pengajaran dengan metode yang menarik minat siswa-siswi untuk belajar. Untuk itu, tim memilih sebuah pengabdian yang dibutuhkan di Desa Sukadana yaitu mengadakan bimbingan belajar di Desa Sukadana. Melalui pendampingan belajar, siswa akan terbantukan dalam mengetasi kesulitan belajar (Handayani et al., 2020; Ismunandar et al., 2020). Mata pelajaran yang dipilih tim yaitu matematika untuk siswa SD, yang pembelajarannya memfokuskan pada perhitungan dasar. Perhitungan dasar yang dipilih oleh anak - anak yaitu perkalian karena hasil belajar siswa pada bab perkalian masih rendah(Restant, 2019). Pada pendampingan ini tim pengabdian akan membimbing anak - anak tentang 
perkalian dengan menggunakan metode garis. Kegiatan ini mengharapkan siswasiswa tingkat SD dapat menguasai perhitungan-perhitungan dasar, khususnya perkalian. Dalam kegiatan ini, siswa-siswi diajarkan sebuah metode perkalian yang lebih mudah dipahami. Selain itu juga, kegiatan ini diharapkan dapat memotivasi siswa-siswi untuk lebih termotivasi dalam belajar matematika. Hasil penelitian Elisa Arisandi (2014: 487) juga menyimpulkan bahwa metode garismatika dapat meningkatkan kemampuan operasi perkalian yang hasil bilangannya dua angka.

\section{Permasalahan}

Berdasarkan analisis situasi di atas, beberapa yang menjadi persoalan dapat didentifikasikan sebagai berikut :

1) Rendahnya kemampuan perhitungan dasar matematika siswa disebabkan oleh kurangnya minat belajar matematika siswa.

2) Kurangnya tenaga pendidik di tempat bimbingan belajar yang bisa meningkatkan minat belajar siswa.

Setelah identifikasi masalah yang telah dilakukan di lokasi rencana program ini dilaksanakan, diperoleh kesimpulan bahwa ada seperangkat permasalahan yang saat ini dihadapi, menyangkut rendahnya minat siswa dalam belajar matematika. Hal ini diduga disebabkan oleh cara guru di sekolah dalam menyelesaikan soal masih menggunakan cara konvensional. Maka permasalahan dalam kegiatan pengabdian pada masyarakat ini adalah masih kurangnya tenaga pendidik sebagai tempat bimbingan belajar dalam meningkatkan kemampuan perhitungan perkalian matematika siswa.

\section{Tujuan}

Kegiatan pengabdian pada masyarakat ini dilaksanakan dengan tujuan untuk meningkatkan kemampuan perhitungan perkalian matematika siswa di Desa Sukadana Kecamatan Tukdana dalam upayah meningkatkan kemampuan perhitungan perkalian matematika siswa melalui pelatihan perhitungan perkalian matematika menggunakan metode garis. Melalui pelatihan perhitungan perkalian menggunakan metode garis berupa kegiatan ceramah dan simulasi, sebanyak kurang lebih 15 orang siswa dilibatkan dalam kegiatan ini. Hasil kegiatan menunjukkan bahwa seluruh peserta menyatakan bahwa program yang dilaksanakan sesuai dengan tujuan yang disasar, peserta sangat antusias untuk mengikuti kegiatan, seluruh peserta aktif dalam mengikuti kegiatan dan peserta mampu menyelesaikan tugas/proyek yang diberikan dengan benar.

\section{B. Metode}

Kegiatan pengabdian dilakukan dengan mengadakan bimbingan belajar selama tiga hari. Terbukti dengan melakukan bimbingan belajar matematika di luar jam sekolah dapat membantu siswa meningkatkan kemampuan kognitifnya, khususnya pada materi operasi perkalian. Pembelajaran dilakukan dengan bantuan metode garis, sehingga siswa memudahkan siswa dalam menyelesaikan operasi perkalian dibandingkan dengan metode menghafal(Paramita et al., 2018).

Untuk mencapai sasaran tersebut maka perlu dilakukan perencanaan kegiatan secara matang. Oleh karenanya, kegiatan yang akan dilaksanakan perlu disosialisasikan dulu kepada khalayak sasaran dengan cara memberikan informasi 
program yang akan dilaksanakan dan sekaligus mengundang peserta untuk berpartisipasi dalam kegiatan yang akan dilaksanakan.

Metode dan strategi yang digunakan dalam pelaksanaan kegiatan ini adalah sebagai berikut :

1. Pada awal kegiatan, siswa akan diberikan materi-materi perkalian yang masih menggunakan cara konvensional.

2. Siswa di berikan latihan soal yang penyelesaiannya masih menggunakan cara konvensional.

3. Tutor kembali memberikan materi yaitu penerapan metode garis untuk menyelesaikan soal perkalian.

4. Siswa kembali diberikan soal latihan yang penyelesaiannya menggunakan metode garis.

5. Siswa diminta untuk membandingkan dua metode penyelesaian tersebut.

Bimbingan belajar diberikan kepada siswa SD yang ada di Desa Sukadana Kecamatan Tukdana. Adapun kegiatan-kegiatan yang akan dilakukan secara garis besar adalah sebagai berikut:

Tabel 1. Jadwal Kegiatan

\begin{tabular}{lll}
\hline No & KEGIATAN & WAKTU \\
$\mathbf{1}$ & Check in peserta & $15.00-15.30$ \\
$\mathbf{2}$ & Pembukaan & $15.30-15.45$ \\
$\mathbf{3}$ & Sesi I Pemberian materi & $15.45-16.00$ \\
$\mathbf{4}$ & Sesi II Latihan soal & $16.00-16.15$ \\
$\mathbf{5}$ & ISTIRAHAT & $16.15-16.30$ \\
$\mathbf{6}$ & Sesi III Pengerjaan Tes & $16.30-16.45$ \\
$\mathbf{7}$ & Penutup & $16.45-17.00$ \\
& Hari Ke dua & \\
$\mathbf{1}$ & Check in peserta & $15.00-15.30$ \\
$\mathbf{2}$ & Pembukaan & $15.30-15.45$ \\
$\mathbf{3}$ & Sesi I Pemberian materi & $15.45-16.00$ \\
$\mathbf{4}$ & Sesi II Latihan soal & $16.00-16.15$ \\
$\mathbf{5}$ & ISTIRAHAT & $16.15-16.45$ \\
$\mathbf{6}$ & Penutup & $16.45-17.00$ \\
& Hari Ke 3 & $15.00-15.30$ \\
$\mathbf{1}$ & Check in peserta & $15.30-15.45$ \\
$\mathbf{2}$ & Pembukaan & $15.45-16.00$ \\
$\mathbf{3}$ & Pemberian motivasi & $16.00-16.30$ \\
$\mathbf{4}$ & Games & $16.30-17.00$ \\
\hline
\end{tabular}

Di setiap pembelajaran sesering mungkin siswa diberikan latihan-latihan soal, karena semakin sering siswa mengerjakan soal bertambah juga keterampilan siswa dalam menyelesaikan soal operasi perkalian. Kami mengharapkan agar kegiatan bimbingan belajar ini dapat dilakukan sebanyak mungkin dan berkelanjutan sehingga siswa tidak merasa kesulitan lagi dalam menyelesaikan soal matematika. 
Untuk menilai keberhasilan program yang dilaksanakan maka perlu dilakukan evaluasi. Secara spesifik aspek, teknik, instrumen serta kriteria evaluasi yang dilakukan dapat disajikan dalam tabel berikut.

Tabel 2. Rancangan Evaluasi

\begin{tabular}{|c|c|c|c|c|}
\hline No & $\begin{array}{c}\text { Aspek } \\
\text { Evaluasi }\end{array}$ & Teknik & Instrumen & Indikator Keberhasilan \\
\hline 1. & Program & Kuisioner & $\begin{array}{l}\text { Angket/ } \\
\text { kuisioner }\end{array}$ & $\begin{array}{l}\text { Kesesuaian program yang } \\
\text { dilaksanakan dengan tujuan } \\
\text { yang disasar. }\end{array}$ \\
\hline 2. & $\begin{array}{l}\text { Proses } \\
\text { pelaksanaan }\end{array}$ & Observasi & $\begin{array}{l}\text {-Daftar } \\
\text { presensi } \\
\text {-Lembar } \\
\text { observasi }\end{array}$ & $\begin{array}{l}\text { - Kehadiran peserta } \\
\text {-Antusiasme peserta } \\
\text {-Aktivitas peserta }\end{array}$ \\
\hline 3. & $\begin{array}{l}\text { Hasil } \\
\text { pelaksanaan } \\
\text { (pengetahuan } \\
\text { dan } \\
\text { kemampuan } \\
\text { peserta) }\end{array}$ & $\begin{array}{l}\text { Pemberian } \\
\text { latihan soal }\end{array}$ & $\begin{array}{l}\text { Hasil } \\
\text { pengerjaan } \\
\text { soal }\end{array}$ & $\begin{array}{l}\text { Kebenaran/kesesuaian } \\
\text { antara latihan yang } \\
\text { diberikan dengan hasil } \\
\text { pengerjaan peserta didik. }\end{array}$ \\
\hline
\end{tabular}

\section{Hasil dan Pembahasan}

\section{HASIL}

Pelaksanaan bimbingan belajar ini dilakukan di rumah posko Desa Sukadana, kegiatan ini dilaksanakan selama 3 hari. Di awal kegiatan ini peserta diberi pendahuluan mengenai perkalian. Menanyakan sejauh mana kemampuan mereka dalam mengoperasikan perkalian dan mendengarkan kesulitan yang dihadapi ketika mengoperasikan perkalian. Selanjutnya, tutor mengajarkan perkalian menggunkan cara konvensional. Hal ini dilakukan agar peserta yang masih belum bisa mengoperasikan perkalian dapat mengetahui cara mengoperasikan perkalian menggunakan teknik dasar.

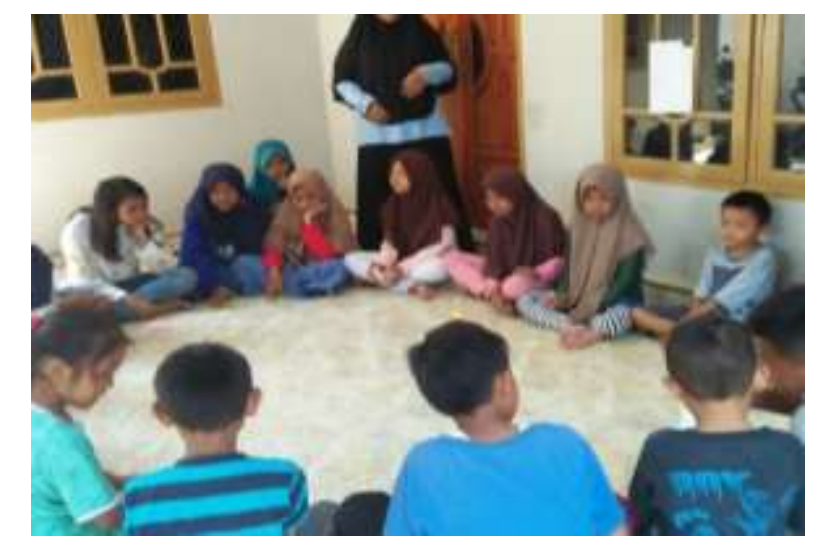

Gambar 1. Proses pengarahan

Setelah peserta mengingat kembali dan memahami pengoperasian perkalian menggunakan cara konvensional, tutor mengarahkan peserta mengisi 
latihan soal. Latihan soal yang dikerjakan masih menggunakan cara konvensional, hal ini dilakukan agar peserta menguasai teknik dasar menggunakan cara konvensional.

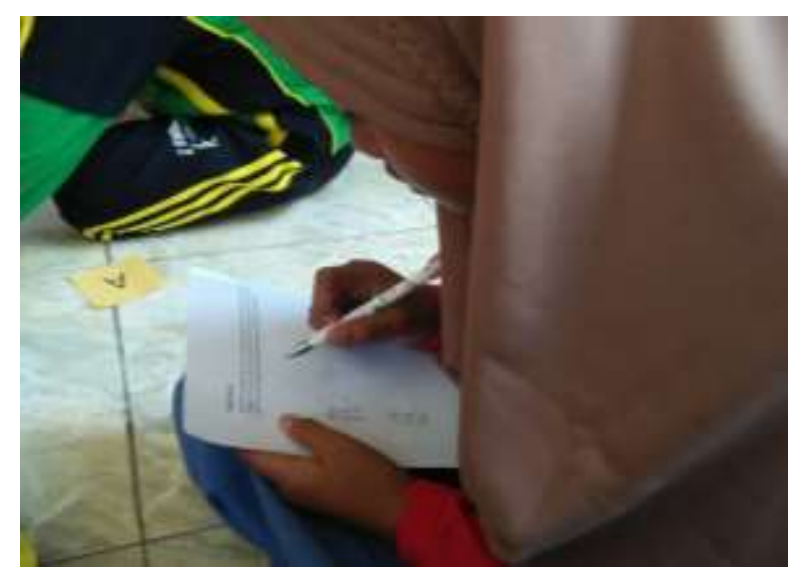

Gambar 2. Tutor memantau langsung pekerjaan peserta

Setelah itu, tutor mengajarkan cara perkalian menggunakan metode garis. Setiap peserta memiliki kemampuan yang berbeda-beda dalam menangkap materi yang diajarkan, sehingga tutor perlu mengecek peserta secara langsung.

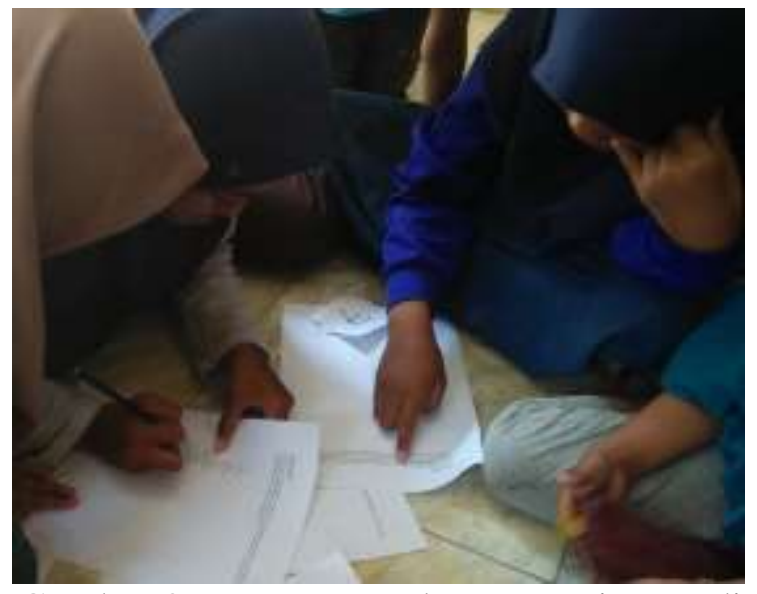

Gambar 3. Tutor mengulang materi yang diajarkan

Tutor mengarahkan peserta mengerjakan ulang latihan soal dengan menggunakan metode garis. Antusias peserta sangat bagus karena menghitung perkalian menggunakan metode garis baru mereka ketahui.

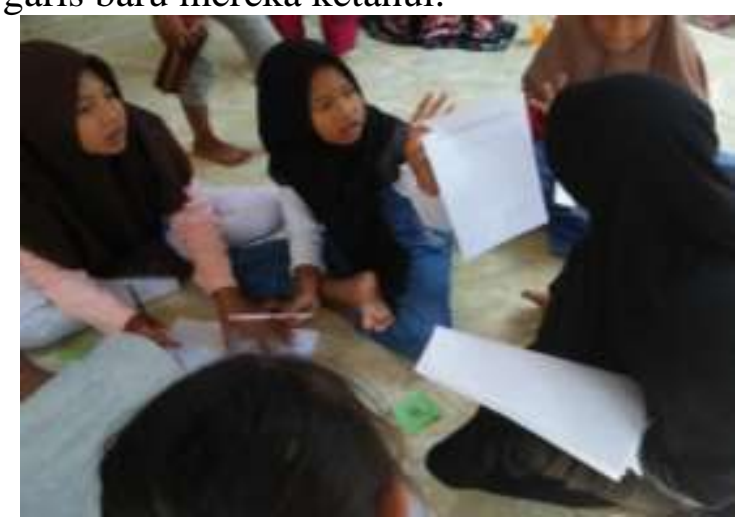

Gambar 4. Mahasiswa berdiskusi dengan peserta didik 
Hasil dari kegiatan ini diperoleh masukan bahwa peserta didik sangat membutuhkan pelatihan menggunakan metode-metode yang dapat memermudah siswa dalam penyelesaian soal. Peserta didik mengharapkan agar kegiatan pengabdian masyarakat ini dapat dilakukan sebanyak mungkin dan berkelanjutan sehingga tetap terjalin komunikasi antar peserta didik, tutor dan univesitas dalam pengembangan materi pelatihan.

\section{PEMBAHASAN}

Selama kegiatan bimbingan belajar ini, para siswa tampak terlibat sangat antusias, banyak pertanyaan muncul terutama pada saat praktek menyelesaikan soal operasi perkalian dengan metode garis. Untuk pertama kalinya siswa belajar matematika dengan metode yang berbeda yaitu metode garis menjadi salah satu alasan siswa bersemangat dalam belajar matematika.

Metode cross line pertama kali di perkenalkan dan dipergunakan oleh masyarakat jepang. Metode cross line adalah suatu cara yang di pergunakan untuk memecahkan perkalian dua digit atau bahkan lebih. Cara ini di gambarkan dengan cara membuat garis yang mewakili nilai satuan, ratusan, ribuan dan seterusnya. Garis yang saling melewati garis satu dengan lainnya akan bertemu dan pertemuan garis ini lah yang akan kita hitung banyaknya atau kita jumlahkan (Sariana dan Harahap, 2017).

Hal lain, menurut Mintarjo (2018) media garis adalah alat bantu pembelajaran yang digunakan oleh guru dalam menerangkan materi pelajaran dan berkomunikasi dengan siswa, sehingga mudah memberi pengertian kepada siswa tentang konsep materi yang diajarkan dengan menggunakan gambar ruas garis atau benda yang menyerupai ruas garis. Untuk menggambar ruas garis tentu bukan hal sulit baik bagi guru maupun siswa seusia sekolah dasar. Namun demikian, agar siswa tidak hanya bisa melihat dan menggambar, ruas garis juga dapat dikonkretkan dengan benda nyata, seperti lidi, bambu, kayu, ranting, dan sebagainya. Media garis ini termasuk media yang mudah dibuat, murah, dan mudah diperoleh di lingkungan yang dekat dengan siswa. Hal ini berarti media ruas garis ini memenuhi syarat sebagai media pembelajaran yang efektif dan efisien.

Di dalam kegiatan pembelajaran siswa perlu melakukan eksplorasi secara aktif dalam rangka mengkonstruksi konsep yang dipelajari sehingga konsep tersebut menjadi bermakna bagi mereka. Hal ini sejalan dengan paham konstruktivisme dari Piaget bahwa siswa membangun pengetahuan pada dirinya, artinya guru tidak memberikan materi secara langsung kepada siswa. Selain itu kegiatan yang melibatkan siswa untuk mengeksplorasi untuk menemukan ide ide baru ataupun memecahkan masalah akan meningkatkan kreativitas siswa (Novita dan Putra, 2016; Ruseffendi, 2006).

\section{Kesimpulan dan saran}

\section{Kesimpulan}

Berdasarkan hasil bimbingan belajar siswa yang dilaksanakan tiga hari bertempat di posko Desa Sukadana dengan menggunakan metode garis terhadap siswa Sekolah Dasar yang ada di desa Sukadana, dapat disimpulkan bahwa 
metode garis lebih mudah dan efektif digunakan oleh siswa dan mampu mengembangkan kemampuan kognitif pada siswa. Hal ini terbukti pada awalnya beberapa siswa mampu menjawab pertanyaan perkalian dengan lambat dikarenakan siswa tersebut memakai cara hafalan yang telah guru ajarkan disekolahnya, dengan adanya pembelajaran menggunakan metode garis tersebut mampu mengembangkan dan meningkatkan kemampuan siswa dalam menyelesaikan operasi perkalian.

\section{Saran}

Guru matematika perlu selalu berusaha meningkatkan kemampuan literasi terkait dengan tugas keprofesioanlannya agar dapat selalu berinovasi dan bervariasi dalam pembelajarannya. Khusus untuk guru matematika pada anak usia sekolah, dalam mengajarkan matematika seyogyanya selalu memperhatikan taraf perkembangan berfikir siswa yang rata-rata masih pada tahap opersioanal konkrit. Siswa pada tahap ini masih memerlukan benda-benda kongkrit dalam memahami konsep-konsep dalam matematika termasuk hitung perkalian bilangan bulat.Sehingga dalam pembelajaran perkalian bilangan bulat seyogyanya guru menggunakan media yang sesuai. Salah satunya adalah dengan menggunakan garis atau manipulasinya.

\section{Daftar Pustaka}

Achadah, A. (2019). Strategi Guru dalam Meningkatkan Motivasi Belajar Siswa Pada Mata Pelajaran Pendidikan Agama Islam Kelas VIII di SMP Nahdhotul Ulama' Sunan Giri Kepanjen Malang. Jurnal Darussalam: Jurnal Pendidikan, Komunikasi Dan Pemikiran Hukum Islam, 10(2), 363. https://doi.org/10.30739/darussalam.v10i2.379

Azhari, B. (2017). Identifikasi Gangguan Belajar Dyscalculia Pada Siswa Madrasah Ibtidaiyah. Al Khawarizmi: Jurnal Pendidikan Dan Pembelajaran Matematika, 1(1), 60. https://doi.org/10.22373/jppm.v1i1.1732

DS, Y. N. (2016). Pengaruh Metode Pembelajaran Dan Motivasi Belajar Siswa Terhadap Hasil Belajar Ipa Kelas V Sdn Cilamaya Wetan Karawang. Jurnal Sekolah Dasar, 1(1). https://doi.org/10.36805/jurnalsekolahdasar.v1i1.70.

Elisa Arisandi. (2014). Meningkatkan Operasi Perkalian untuk Anak Diskalkulia Melalui Metode Garismatika. Jurnal Ilmiah Pendidikan Khusus. Vol.3 No.3

Handayani, T., Khasanah, H. N., \& Yoshinta, R. (2020). Pendampingan Belajar Di Rumah Bagi Siswa Sekolah Dasar Terdampak Covid-19. ABDIPRAJA (Jurnal Pengabdian Kepada Masyarakat), 1(1), 107-115. https://doi.org/10.31002/abdipraja.v1i1.3209

Ismunandar, D., Rosyadi, R., Nandang, N., \& Aziz, K. (2020). Pendampingan Belajar Matematika Pada Materi Pecahan di Desa Lajer Kecamatan Tukdana Kabupaten Indramayu. Abdi Wiralodra, 2(1), 45-56.

Mintarjo, M. (2018). Perkalian Bilangan Bulat Dengan Media Garis. Prosiding Sendika, 4(1).

Novita R and Putra M (2016) Using Task Like Pisa' S Problem To Support Student' SMath. Educ. 7 31-42

Paramita, D., M.S, Z., \& Noornia, A. (2018). Penggunaan Media Garismatika 
Sebagai Upaya Meningkatkan Pemahaman Konsep Perkalian Pada Mata Pelajaran Matematika. JPD : Jurnal Pendidikan Dasar, 9(1), 40-53.

Restant, I. M. (2019). Upaya Meningkatkan Kemampuan Mengalikan Bilangan cacah dengan Menggunakan Metode Perkalian Untuk Siswa Kelas II SDN.Setia Asih 05 Tahun 2017/2018 Indri. Bina Manfaat Ilmu: Jurnal Pendidikan, 2(2), 1-34.

Sariana, N., \& Harahap, H. P (2017). Pembuatan Animasi 2 Dimensi untuk Meningkatkan Minat Belajar Perkalian pada Para Siswa Kelas 2 Sekolah dasar dengan Metode Frame By frame dan Metode Cross Line. Jurnal Pendidikan, 3(1).

Sari, B., Saadati, B. A., \& Sadli, M. (2019). Peningkatan Motivasi Belajar Siswa Melalui Penerapan Metode Hypnoteaching Pada Mata Pelajaran IPS Siswa Kelas V SD Nurul Ijtihad Pujut Lombok Tengah. ElementerIs, 1(2), 10-19. https://doi.org/10.1142/S0217984921502900.

Sari, Y. W. (2015). Pengaruh Bimbingan Belajar terhadap Hasil Belajar Matematika Siswa kelas IV di Sekolah Dasar (Doctoral dissertation, State University of Surabaya).

Sholihah, D. A., \& Mahmudi, A. (2015). Keefektifan Experiential Learning Pembelajaran Matematika MTs Materi Bangun Ruang Sisi Datar. Jurnal $\begin{array}{llll}\text { Riset Pendidikan } & \text { Matematika, }\end{array}$ https://doi.org/10.21831/jrpm.v2i2.7332

Siregar, N. R. (2017). Persepsi Siswa Pada Pelajaran Matematika: Studi Pendahuluan Pada Siswa yang Menyenangi Game. Prosiding Temu Ilmiah X Ikatan Psikologi Perkembangan Indonesia, 224-232.

Supriatna, I., Yuliawati, N. D., \& Firmansyah, W. (2017). Bimbingan belajar terhadap hasil belajar matematika. Didaktika Tauhidi: Jurnal Pendidikan Guru Sekolah Dasar, 4(1).

Yeni, E. M. (2015). Kesulitan Belajar Matematika Di Sekolah Dasar. Jupendas, 2(2), 1-10. 